\title{
BIAS IN COLLEGIATE COURTS
}

\author{
Abimbola A. Olowofoyeku*
}

\begin{abstract}
This article addresses the issues attending common law collegiate courts' engagements with allegations of bias within their own ranks. It will be argued that, in such cases, it would be inappropriate to involve the collegiate panel or any member thereof in the decision, since such involvement inevitably encounters difficulties. The common law's dilemmas require drastic solutions, but the common law arguably is illequipped to implement the required change. The answer, it will be argued, is legislation.
\end{abstract}

Keywords: bias, collegiate courts, fair hearing, judicial impartiality, recusals.

Where ... a member of a court or tribunal sitting with others incorrectly declines to recuse himself or herself from the hearing, that particular decision may well have the effect of fatally contaminating the ultimate decision of the court or tribunal. ${ }^{1}$

\section{INTRODUCTION}

The above statement highlights a potential problem for judges of multi-member courts or tribunals (hereafter, 'collegiate courts'), that of the prospect of thirdparty or second-hand ' 'contamination'. Exemplifying the 'fatal contamination' concept, Lord Phillips MR explained in In Re Medicaments, after establishing a judge's disqualification, that;

Having reached this decision, we then had to consider the position of the other two members of the Court ... We concluded that it was inevitable that the decision that [the judge] should be disqualified carried with it the consequence that the other two members of the Court should stand down. ${ }^{3}$

Collegiate courts typically exercise appellate/review jurisdictions, confronting bias/recusal issues in the context of challenges to decisions of lower bodies.

\footnotetext{
* Professor of Law, Brunel University, London, abimbola.olowofoyeku@brunel.ac.uk.

1 Majiedt $\mathrm{J}$ in Hendrikse v Northern Cape Liquor Board [2003] ZANCHC 34, [9] (HC, Northern Cape).

2 A Smith J in ASM Shipping Ltd v Bruce Harris [2007] EWHC 1513 (Comm), [44].

3 Director General of Fair Trading v Proprietary Association of Great Britain [2000] EWCA
} Civ 350, [2001] WLR 700, [98]-[99]. 
However, they are not themselves immune from bias allegations. How should they respond to the risk of contamination due to bias on the part of a member?

As judges become less insulated from general societal life and commercial, scholarly, community or charitable endeavours, so will increase the possibilities of actions or words triggering objections to their sitting in particular cases. The potential for objection also rises in proportion to the number of judges sitting, reflecting the numerical increase in the potentially compromised, whether due to events occurring before or during the case itself. Such objections are increasingly common in connection with Tribunals $^{4}$ and other similar bodies. ${ }^{5}$ The range of susceptible bodies is wide, including, for example, a Court Martial ${ }^{6}$ and an Appeal Board appointed by a Finance Minister. ${ }^{7}$ Even when no objection is raised, there may still be sufficient concern for the matter to be voiced elsewhere. ${ }^{8}$

The nature and potential scale of the problem can be gleaned from a cursory examination of some recent cases involving senior courts. The Irish Court of Appeal in $O^{\prime}$ Driscoll (minor) v Hurley ${ }^{9}$ faced an application that Irvine $\mathrm{J}$ should recuse herself from the panel on the ground that an address that she had delivered on aspects of medical negligence litigation at a medico-legal conference gave rise to a reasonable apprehension of bias. The Court, in a judgment delivered by Irvine $J$ herself, rejected the application. The New Zealand Court of Appeal in Orlov v National Standards Committee no $1^{10}$ unanimously rejected an application for French $\mathrm{J}$ to recuse herself from hearing the appeal. In Government of Seychelles v Seychelles National

${ }^{4}$ For some recent examples, see eg, East of England Ambulance Service NHS Trust $v$ Sanders [2015] ICR 293, [2015] IRLR 277 (EAT); Employment Rights Advice Ltd v Mrs C Thew, Reaseheath College, UKEAT/0382/14/JOJ (EAT, 20 March 2015); Taylor $v$ The Governing Body of the Potters Gate CE Primary School, UKEAT/0227/14/DXA (EAT, 27 February 2015); Begraj v Heer Manak Solicitors [2014] IRLR 689, [2014] ICR 1020 (EAT); Papajak v Intellego Group Ltd, Intellego Holdings plc, Zenosis Ltd, UKEAT/0124/12/JOJ (EAT, 3 June 2014); Her Majesty's Attorney General v Iteshi, UKEAT/0435/13/RN (EAT, 12 March 2014); Aziz v Crown Prosecution Service, UKEAT/0027/13/LA (EAT, 21 November 2013).

5 There is a glut of cases on this. Some of the most recent examples include; $R$ (Antino) $v$ Royal Institute of Chartered Surveyors (Appeal Panel) [2015] EWHC 2457 (Admin); Nicholas-Pillai v The General Medical Council [2015] EWHC 305 (Admin); Prasad v General Medical Council [2015] EWHC 338 (Admin); $R$ on the Application of Yash Mehey, Josephine Hayes, Carron-Ann Russell v Visitors to the Inns of Court v Bar Standards Board [2014] EWCA Civ 1630; McDaid v Nursing and Midwifery Council [2014] EWHC 1862 (Admin); Amao v Nursing and Midwifery Council [2014] EWHC 147 (Admin); P (A Barrister) v General Council of the Bar [2005] 1 WLR 3019, [2005] PNLR 32 (Visitors to the Inns of Court); Rasool v General Pharmaceutical Council [2015] EWHC 217 (Admin).

${ }^{6}$ See eg Commander of the Lesotho Defence Force and Others $v$ Maluke [2014] LSCA 42, [2015] 3 LRC 486 (CA, Lesotho).

7 Belize Bank Ltd v Attorney General and Others [2011] UKPC 36, [2012] 3 LRC 273.

8 See eg Sir Terence Etherton C in Newbound $v$ Thames Water Utilities Limited [2015] EWCA Civ 677, [88]-[94].

9 [2015] IECA 158. Noted in SM Garcia, 'Case Comment Appeal from High CourtAdequacy of Damages’ (2015) 21(2) Medico-Legal Journal of Ireland 104.

${ }^{10}[2014]$ NZCA 242. 
Party $^{11}$, the Seychelles Court of Appeal overturned a majority Constitutional Court decision which ordered the recusal of a member of the panel (who had declined to recuse himself), and directed that he should not sit. In 2013, Gageler $\mathrm{J}$ of the High Court of Australia in Unions NSW v New South Wales $^{12}$, recused himself from the appeal on account of signed legal advice that he, as Solicitor-General, had given advice to the Attorney-General on a piece of legislation the validity of which was at issue. Fortunately, this happened at the start of the proceedings, and the Court was able to reconstitute without his participation. However, the New Zealand Supreme Court in Saxmere Company Ltd v Wool Board Disestablishment Company Ltd (No 2) ${ }^{13}$ recalled its earlier judgment in the case because Wilson $\mathrm{J}$ had failed to recuse himself from that appeal and to make full disclosure of an apparently disqualifying interest. ${ }^{14}$ This issue is also very much alive in international law and arbitration. ${ }^{15}$ These recent examples also spotlight some of the problems that may arise in and from such situations.

Bias allegations may relate to a judgment, in respect of which relief is sought in the deciding court itself or in a higher court. They may also arise in ongoing/ current proceedings before a court. Each raises different issues, but the consequences of an erroneous decision can be equally grave. The argument presented here relates mainly to the latter situation, but completeness requires consideration of the former also. The implications of the disqualification of a member of a collegiate court for the other members have been described as 'the rotten apple in the barrel test'. ${ }^{16}$ The court's judgment apparently becomes tainted, ${ }^{17}$ and may be quashed by a higher court or, in the case of an apex court, be set aside if such a response is available. The House of Lords followed the latter course in the Pinochet ${ }^{18}$ case, about which more will be said later. One apparent reason for possibly treating the decision of a collegiate court as 'fatally contaminated' by the participation of a disqualified member is, according to Gummow $\mathrm{J}$ in $I W v$ City of Perth, ${ }^{19}$ because 'in bias

11 [2014] SCCA 33.

12 [2013] HCATrans 263 (5 November 2013).

13 [2009] NZSC 122, [2010] 1 NZLR 76. Noted in H Wilberg, 'Supreme Court recalls judgment in recusal case after one of its own members makes fuller disclosure of relationship with counsel before him in a Court of Appeal case' [2010] PL 422; R Cornes, 'Saxmere Co Ltd v Wool Board Disestablishment Co Ltd (Saxmere 1): Editor's Introduction: New Zealand Supreme Court justice under investigation for alleged misconduct' [2010] PL 411.

14 On the consequences of this for Wilson J, see BV Harris 'New Zealand: Supreme Court judge resigns - saga raises questions about recently enacted judicial complaints legislation' [2011] PL 436.

i5 See eg JK Sharpe, 'Introductory Note to the Arbitral Tribunal Constituted Under Annex VII of The 1982 United Nations Convention on The Law of The Sea: Republic of Mauritius v. United Kingdom \& Northern Ireland, Reasoned Decision On Challenge' (2012) 51 ILM 350.

${ }_{16}$ Spigelman CJ in McGovern v Ku-Ring-Gail Council [2008] NSWCA 209, [31] (CA, NSW).

17 Compare Davidson v Scottish Ministers, 2003 SC 103, [35] (upheld by the House of Lords, [2004] UKHL 34); Millar v Dickson [2002] SC (PC) 30, [65]; De Haan v Netherlands (1998) 26 EHRR 417; Aetna Life Insurance Co. v Lavoie, 475 US 813 (1986).

${ }^{18} R v$ Bow Street Metropolitan Stipendiary Magistrate, ex p Pinochet Ugarte (No 2) [2000] 1 AC 119 .

19 (1997) 191 CLR 1, 50-51 (HC, Australia). 
cases the court does not enter into difficult evidentiary questions as to the extent to which that person may have influenced the majority'. ${ }^{20}$ On the other hand, the Supreme Court of Canada seemed to doubt in Wewaykum Indian Band $v$ Canada ${ }^{21}$ ('Wewaykum') that the disqualification of a judge in circumstances wherein his or her vote did not swing the decision would be a sufficient basis for vacating the judgment of the court. This remains a contentious issue.

This discussion aims to establish that the common law approaches, which mostly involve decisions by the impugned judge and/or the collegiate panel, are defective. It will be argued that the need to maintain public confidence in the administration of justice makes it inappropriate for bias claims in collegiate courts to be determined by the impugned judge or the panel wherein that judge is or was sitting. But, since the common law is well established, and the required change engages difficult questions that the common law is unable to address satisfactorily in adversarial litigation, the matter ought to be resolved by legislation removing the decision entirely from the affected collegiate panel or any member thereof.

In developing this thesis, I will first examine briefly the relevant principles and standards of the rule against bias, following which I will address the special focus on collegiate courts. This will be followed by consideration of the approaches to reopening judgments and to current proceedings in a number of common law jurisdictions. ${ }^{22}$ The discussions will focus mainly on the UK, US Federal law, and Commonwealth collegiate courts that have confronted internally the issue of bias. These jurisdictions have generated between them a body of case law that sufficiently illuminates the issues and the possible approaches thereto. The object of this comparative analysis is not to distil the 'right' common law approach, ${ }^{23}$ but, to demonstrate that attempts to address the issues via judicial decision-making invariably run into difficulties that cannot be resolved satisfactorily by the courts on their own. Legislative intervention is warranted, and it will be contended that legislating for independent adjudication ${ }^{24}$ of bias/recusal applications by designated judges or a specially constituted panel of judges would be the best way to address the issues.

${ }^{20}$ See the detailed discussions on this point in McGovern v Ku-Ring-Gail Council, [2008] NSWCA 209 (Spigelman CJ at [31]-[48]; Basten JA at [97]-[103]).

${ }^{21}$ [2003] 2 SCR 259, [91]-[93].

22 In this discussion I include Scotland and South Africa in the 'common law family', because of the strong influences of common law jurisprudence on their jurisprudence on judicial bias. Any potential conflict between Scottish and English law 'has been removed' (Lord Hope of Craighead in Gillies v Secretary of State for Work and Pensions [2006] UKHL 2, [2006] 1 WLR 781, [3]), and the leading South African cases are routinely being cited in UK decisions (and vice versa).

${ }^{23}$ See generally, J Bell, 'The Argumentative Status of Foreign Legal Arguments' (2012) Utrecht Law Review 7.

${ }^{24}$ By 'independent adjudication' in this context I mean adjudication outwith the affected collegiate panel. 


\section{THE RULE AGAINST BIAS}

The 'rule against bias', a pillar of the common law's quest for judicial impartiality, seeks to ensure that justice is done, and 'seen to be done'. ${ }^{25}$ The applicable principles and standards are clear, and the debates tend to revolve around their proper application to specific factual situations. The rule disqualifies judges from sitting in cases wherein they have an interest, ${ }^{26}$ or (in US Federal law) their impartiality might reasonably be questioned, ${ }^{27}$ or, there is (in the UK) a 'real possibility', 28 or (elsewhere in the Commonwealth), a 'reasonable apprehension' or 'reasonable suspicion'29 of bias. The standard is objective. In English law the question is "whether the fair-minded and informed observer, having considered the facts, would conclude that there was a real possibility that the tribunal was biased'. ${ }^{30}$ This approach is consistent with the jurisprudence of the European Court of Human Rights ${ }^{31}$ ('ECtHR'). It is about appearances, ${ }^{32}$ which are 'just as important as the reality' 33 and is considered essential in protecting 'public confidence' in the administration of justice. ${ }^{34}$ As the High Court of Australia said in Ebner v The Official Trustee in Bankruptcy, "So important is the principle that even the appearance of departure from it is prohibited lest the integrity of the judicial system be undermined'. 35

Case law and academic commentary on bias often focus on the actual decision reached, ie, whether the impugned judge(s) should have sat or not, rather than the process whereby that decision was reached. The attraction of such a focus is obvious. As Sir Terence Etherton $\mathrm{C}$ noted in Resolution Chemicals Ltd v H Lundbeck $A / S$, '[c] ases of subconscious bias ultimately

${ }^{25} R v$ Sussex Justices ex p McCarthy [1924] 1 KB 256, 259; Millar v Dickson [2002] SC 30 (PC), [63].

26 Dimes v Proprietors of Grand Junction Canal (1852) 3 HL Cas. 759; Sellar v Highland Railway Co, 1919 SC (HL) 19; Pinochet (n 18); Meerabux v AG of Belize [2005] UKPC 12.

2728 USC section 455(a); compare Canon 2 of the ABA Model Code of Judicial Conduct.

${ }_{28}$ Porter v Magill [2001] UKHL 67; Lawal v Northern Spirit Limited [2003] UKHL 35; Davidson v Scottish Ministers [2004] UKHL 34.

${ }^{29} R v$ Webb [1994] HCA 30, (1994) 181 CLR 41 (HC, Australia); Auckland Casino Ltd. v Casino Control Authority [1995] 1 NZLR 142 (CA, New Zealand); $R$ v S (RD) (1997) 151 DLR (4th) 193 (SC, Canada); SACCAWUv Irvin \& Johnson [2000] ZACC 10 (Const. Ct., South Africa).

${ }^{30}$ Lord Hope in Porter v Magill, [103].

31 ibid. Also, O'Neill v HM Advocate (No 2) [2013] UKSC 36 (Lord Hope at [47]). Apparently, despite differences in formulation, the English and Irish positions are the same-see Finnegan J in The People (at the suit of The Director of Public Prosecutions) v Norris [2011] 2 IR 112, [16] (CCA, Ireland), as are apparently the Australian and New Zealand positions (see Blanchard J in Saxmere Company Limited and others $v$ Wool Board [2009] NZSC 72, [3] (SC, New Zealand)).

32 See eg Scalia J in Liteky v US, 127 L. Ed. 2d. 474, 486 (1994); Hauschildt v Denmark (1989) 12 EHRR 266, [48].

${ }^{33}$ Lord Nolan in Pinochet, [2000] 1 AC 119, 139.

34 See eg Lord Bingham of Cornhill in Davidson v Scottish Ministers [2004] UKHL 34, [7]; Lord Denning MR in Metropolitan Properties Ltd v Lannon [1969] 1 QB 577, 599; Frankfurter J in Public Utilities Comission v Pollak, 343 US 451, 476 (1952); Spear J in Sun Exploration and Production Co v Jackson (1989) 783 SW 2d 202, 206 (Texas, 1989).

${ }_{35}$ [2000] HCA 63, [3] and [6]-[7]. 
turn on the particular facts of the case' ${ }^{36}$ A recusal decision by a judge 'is a multi-factorial decision', ${ }^{37}$ and the 'factual context is critical'. ${ }^{38}$ Many recusal decisions will therefore be controversial and susceptible to evaluative commentary against the factual background and the legal framework. But this present discussion is not about the recusal standards, their application to individual cases, the 'correct' response to specific factual situations, or existing principles/guidelines on bias. Rather, it is about who ought to decide, and how the decision ought to be taken. Resolving those questions involves engaging contentious questions of process and jurisdiction, which this article will address.

\section{THE ISSUE WITH COLLEGIATE COURTS}

Bias in collegiate courts raises unique difficulties. Recusal applications before single-judge courts normally raise no questions as to who the decision-maker should be or how the decision ought to be taken. The impugned judge would normally be expected to decide the matter personally, and an error would affect only that judge's decision. Collegiate court judges, however, may be implicated by the disqualification of others, and their work may end up being undone if one of their colleagues were to err in the matter of self-recusal. Thus, each member of a collegiate court panel has a legitimate interest in the impartiality (actual and apparent) of the others. ${ }^{39}$ Furthermore, some collegiate courts may have complex internal dynamics or ideological divisions, the significance of which cannot be underestimated. Thus judges may be reluctant to interfere in the affairs of their colleagues..$^{40}$ Where an apex collegiate court is involved, additional issues, including finality in litigation, arise.

For a collegiate court, resolving a challenge to a judgment on grounds of bias may involve two different scenarios. If the challenge is raised in a higher court (the 'first scenario'), that court has to decide whether the impugned member of the lower court was disqualified. If so, the question is whether the decision ought to be set aside. If the challenge to a judgment is raised in the deciding court itself (the 'second scenario'), questions arise as to the circumstances (if any) wherein the court has the jurisdiction to recall or reopen the judgment on account of the alleged bias, the proper process for reopening the judgment, and whether the judgment can/should be vacated if it is decided

36 [2013] EWCA Civ 1515, [2014] 1 WLR 1943, [37].

37 At [41].

38 At [42]; see also Higgins LJ in Rv Martin Raymond Jude Murray \& Ors [2015] NICA 54, [63]; Carr J in Rasool v General Pharmaceutical Council [2015] EWHC 217 (Admin), [30]; Lebel J in Imperial Oil Ltd. v Quebec (Minister of the Environment) [2003] 2 SCR 624, 2003 SCC 58, [31] (SC, Canada).

39 See Glazebrook J in $R v$ Chatha [2008] NZCA 466, [16] (CA, New Zealand).

40 See KL Henke, 'If it's not Broke, Don't Fix It: Ignoring Criticisms of Supreme Court Recusals' [2013] StLouisULJ. 521, 531-3. 
that the challenge is well founded. A further question is whether the disqualification of one member automatically 'fatally contaminates' the court's decision. This is relevant to both scenarios, and the second scenario will be used as a proxy for that discussion. A different situation emerges when challenges to a judge's participation are raised during current/ongoing proceedings (the 'third scenario'). Here, questions arise as to the proper process for raising the bias question, who is entitled to decide the matter, how the process ought to be managed, and the remedy for a party aggrieved by the ensuing decision. The case law reveals a range of approaches by common law courts to these scenarios. Particularly noteworthy are the often unsatisfactory responses in current/ongoing proceedings.

In Re Medicaments illustrates the first and third scenarios. The Restrictive Practices Court (presided over by Lightman J) faced an application for a member to recuse herself for apprehended (or apparent) bias ${ }^{41}$, and for the Court, being tainted by that bias, to recuse itself. Following the judge's refusal to recuse herself, Lightman $J$ said that the Court must, in the circumstances, 'decide (in effect if not in form) whether she is wrong, for the Court must independently decide the question whether she should recuse herself as the preliminary to deciding whether the Court should accede to the application that the Court should recuse itself'. ${ }^{42}$ The Court ultimately dismissed the recusal applications. The Court of Appeal ${ }^{43}$ held that the judge should have recused herself. This also meant that the other members of the court were disqualified, and the judgment was set aside. For the impugned judge to take the initial decision is consistent with common law doctrine. It is, however, problematic in the context of collegiate courts. Lightman J seemed to have proceeded on the basis that the Court could examine the correctness of the judge's decision (ie, that the collegiate panel could effectively constitute itself into an appellate tribunal over the judge's recusal decision). The Court of Appeal did not comment on this approach. Nevertheless, it raises questions, which will be examined later.

The Pinochet case ${ }^{44}$ exemplifies the second scenario. The House of Lords vacated its judgment in the case on the ground that Lord Hoffmann, one of the majority in a 3-2 decision, sat on the committee deciding the case while disqualified. The House's approach also raises questions, and the decision has rightly been criticized. ${ }^{45}$

\footnotetext{
41 'Apprehended' or 'apparent' bias is a technical term normally used in respect of cases where 'actual' bias is not being alleged (ie, in situations where it is claimed that an 'informed observer' would consider that there is a 'real possibility' of bias).

43 [2000] EWCA Civ 350.

42 [2000] All ER (D) 1895, [16].

44 [2000] 1 AC 119.

45 See eg P Havers QC and O Thomas, 'Bias Post-Pinochet and Under the ECHR' [1999] JR 111; A Olowofoyeku, 'The Nemo Iudex Rule: The Case against Automatic Disqualification' [2000] PL 456; J Maurici, 'The Modern Approach to Bias' (2007) 12 JR 251 (contrast A Finucane, 'Automatic Disqualification on Grounds of Objective Bias: A Case for Retention' (2014) 4 King's Inns Student Law Review 73, arguing for retention of automatic disqualification). For
} 
The discussion that follows examines various approaches to the above scenarios.

\section{REOPENING JUDGMENTS}

This concerns the 'second scenario' discussed above. Common law apex courts typically assert the jurisdiction to reopen their own judgments on grounds of bias. In the Pinochet case, vacation by the House of Lords of its original judgment prompted a direction for a rehearing of the appeal before a differently constituted committee of the House. ${ }^{46}$ However, the question whether, upon finding that Lord Hoffmann was disqualified, the rest of the original committee must also be disqualified, was not addressed directly. The rationale for ordering a rehearing before a different committee was not stated to be the fatal contamination of the rest of the first committee, but, rather, 'so that on the rehearing the parties were not faced with a committee four of whom had already expressed their conclusion on the points at issue' 47 (which may be another way of saying that the rest of the original committee must necessarily be disqualified).

The Supreme Court of Canada was willing in principle in Wewaykum ${ }^{48}$ to assume a similar jurisdiction to reopen, and, if appropriate, vacate its own decision, but rejected the application to vacate it on the merits. The Court appeared to indicate that, since each judge on the panel came to his or her own decision 'independently', bias on the part of one Justice would not necessarily vitiate the Court's decision. ${ }^{49}$ The focus seemed to be on the impact of a member's vote, rather than on the member's participation. The Ontario Divisional Court accepted this approach in Sos-Save Our St. Clair Inc. $v$ City of Toronto ${ }^{50}$ ('SOS'). However, the problem in a bias case is arguably the participation of a disqualified judge. Even when that judge's vote does not swing the decision, there is no way of evaluating the impact of the judge's participation on the others.

Like the House of Lords in Pinochet, the Supreme Court of Ireland in Kennyv Trinity College ${ }^{51}$ vacated one of its own judgments on grounds of apprehended bias. The issue had previously been addressed in Bula Ltd v Tara Mines Ltd $(\text { No 6 })^{52}$ where it was established that the Court had this jurisdiction in certain circumstances. ${ }^{53}$ In Talbot $v$ McCann Fitzgerald Solicitors, ${ }^{54}$ failure

other analyses, see G Henry, 'Pinochet: In Search of the Perfect Judge' (1999) 21 SydLR 667; K Malleson, 'Judicial Bias and Disqualification after Pinochet (No. 2)' (2000) 63(1) MLR 119.

46 The UK Supreme Court has inherited this jurisdiction to reopen its own judgments (see Lord Hope DP in $R$ (Edwards and another) $v$ Environment Agency (No 2) [2010] UKSC 57, [35]). With regard to the jurisdiction of the Court of Appeal to reopen an appeal, see Taylor v Lawrence [2002] EWCA Civ 90, [2003] QB 528.

47 Lord Browne-Wilkinson, [2000] 1 AC 119, 137.

49 [2003] 2 SCR 259, [91]-[93]. $\quad{ }^{50}$ (2005) 18 CPC (6th) 286.

48 [2003] 2 SCR 259.

52 [2000] 4 IR 412.

53 See also Talbot $v$ Hermitage Golf Club [2009] IESC 26; DPP v McKevitt [2009] IESC 29.

54 [2009] IESC 25, [31.10]. 
to discharge 'the heavy burden of establishing that such exceptional circumstances' exist was treated as depriving the court of jurisdiction. Such linking of the merits to jurisdiction (ie, 'procedure informs substance'55) may have a powerful restrictive impact.

The New Zealand Court of Appeal in Man O'War Station Ltd v Huruhe Station $L t d^{56}$ reviewed its earlier decision on grounds of apprehended bias, but declined to vacate it. Subsequently the New Zealand Supreme Court vacated an earlier judgment in Saxmere Company Ltd $v$ Wool Board Disestablishment Company Ltd (No 2). ${ }^{57}$ In so doing, it did not regard the perfection ${ }^{58}$ of the judgment as an impediment. ${ }^{59}$ Similarly, the High Court of Australia was willing in State Rail Authority of NSW $v$ Codelfa Construction Pty Ltd ${ }^{60}$ (not a bias case) to review its own decision. While there 'may be little difficulty' when the judgment has not been perfected, ${ }^{61}$ perfection is possibly no impediment, ${ }^{62}$ and suitable cases may not be limited to denials of fair hearing. ${ }^{63} \mathrm{~A}$ similar approach has been taken by the Constitutional Court of South Africa, ${ }^{64}$ by the East African Court of Justice, ${ }^{65}$ and by the Caribbean Court of Justice. ${ }^{66}$

Apparently swimming against this tide is the Supreme Court of the United States, wherein the recusal of Justices is considered a matter for the individual Justices only. ${ }^{67}$ This is an 'under-discussed' and 'historic practice', that is 'truly a creature of tradition'. ${ }^{68}$ A recusal motion is treated

55 See TE Baker, A Primer on the Jurisdiction of the U.S. Courts of Appeals (2nd edn, Federal Judicial Center 2009), 32.

${ }_{57}$ [2000] NZCA 352 (affirmed by the Privy Council, [2002] 3 NZLR 577, [2002] UKPC 28).

57 [2009] NZSC 122, [2010] 1 NZLR 76. Noted in H Wilberg, 'Supreme Court recalls judgment in recusal case after one of its own members makes fuller disclosure of relationship with counsel before him in a Court of Appeal case' [2010] PL 422; R. Cornes, 'Saxmere Co Ltd v Wool Board Disestablishment Co Ltd (Saxmere 1): Editor's Introduction: New Zealand Supreme Court justice under investigation for alleged misconduct' [2010] PL 411.

58 In England, a judgment or order is now 'perfected by being sealed by the court' under CPR 1998, r.40.2(2)(b) (per Baroness Hale of Richmond, JSC in In re L and another (Children) (Preliminary Finding: Power to Reverse), [2013] UKSC 8; [2013] 1 WLR 634, [19]). With respect to Australia, compare E Campbell, 'Revocation and Variation of Administrative Decisions' (1996) 22 MonLR 30, 33-'The judgments and orders of courts of record are not perfected until they have been formally passed and entered in the court's records' (internal $\begin{array}{lll}\text { citations omitted). } & \text { [2009] NZSC 122, [2]. } & \text { (1982) 150 CLR } 29 .\end{array}$

61 Mason and Wilson JJ (1982) 150 CLR 29, 38-39.

62 University of Wollongong v Metwally (No 2) (1985) 59 ALJR 481, 482.

63 Mason CJ in Autodesk Inc v Dyason (No 2) (1993) 176 CLR 300, 302-303; also Elliott v R (2007) 234 CLR 38.

${ }^{64}$ In President of the Republic of South Africa $v$ South African Rugby Football Union ('SARFU') [1999] ZACC 9, 1999 (4) SA 147.

${ }^{65}$ AG of Kenya v Prof. Anyang' Nyong'o ('Nyong'o') [2007] EACJ 1 (6 February 2007), available at $<$ http://www.saflii.org/ea/cases/EACJ/2007/1.pdf $>$.

66 Browne v Moore-Griffith (No 2) [2013] CCJ 12 (AJ), (2013) 84 WIR 76.

67 See eg Jackson J in Jewell Ridge Coal Corp. v Local No. 6167, 325 US 897, 897 (1945).

68 R Pearson, 'Duck Duck Recuse? Foreign Common Law Guidance \& Improving Recusal of Supreme Court Justices’ (2005) 62 Washington and Lee Law Review 1799, 1813-14. 
as being addressed to the impugned Justice personally, ${ }^{69}$ and a Justice's decision on that issue is unreviewable. ${ }^{70}$ The reluctance of the Supreme Court Justices to recuse themselves, and their justifications or excuses for not doing so, are well documented. ${ }^{71}$ From the viewpoint of an ideologically split court, ${ }^{72}$ this historic approach may appear to be sensible. But there are also jurisdictional questions that would emerge from a different approach. Additionally, there is a supposed complication arising from the constitutional mandate of 'one Supreme court'. ${ }^{73}$ Also pertinent is the shift in the balance of power and possible allegations of political bias that would attend a decision of a majority of Justices to 'vote off' one of their colleagues. There thus seems to be little prospect of the Court vacating its own judgment on the grounds that a Justice had sat while disqualified. It has been suggested that a move to reopen a previous decision, force non-recusing Justices to recuse themselves, reverse the previous decision, and fashion a remedy, might precipitate a 'dangerous Constitutional crisis'. ${ }^{74}$ The power to recall a mandate $^{75}$ in 'extraordinary circumstances', for 'grave, unforeseen contingencies', ${ }^{76}$ and, the 'rehearing rule', ${ }^{77}$ are probably inappropriate for these purposes. In any event, since no error arises from Justices' recusal decisions, there would be no basis for a recall/rehearing petition.

In sum, (with the exception of the US Supreme Court), the inherent but highly exceptional jurisdiction of an apex collegiate court to vacate its own decision on grounds of the disqualification for bias of one of its members is widely recognized in common law jurisdictions. Safeguarding public confidence in the administration of justice makes this desirable, and the situation with regard to the US Supreme Court is unfortunate. What is not so clear is whether one member's disqualification is always a fatal contaminant. This is a fundamental question, and it is surprising that it is yet to be resolved definitively. Ultimately, the answer arguably is dependent upon what would best uphold public confidence in the administration of justice. This will be returned to later.

69 See eg Rehnquist J in Hanrahan v Hampton, 446 US 1301 (1980).

70 Jackson J in Jewell Ridge (n 67).

71 See eg R Saidman-Krauss, 'A Second Sitting: Assessing the Constitutionality and Desirability of Allowing Retired Supreme Court Justices to Fill Recusal-Based Vacancies on the Bench' (2011-12) 116 Penn State Law Review 253.

72 See for example the strident critique of Bush v Gore, 531 US 98 (2000) in J Balkin, 'Bush v. Gore and the Boundary Between Law and Politics' (2001) 110 YaleLJ 1407. Balkin (at 1408) refers to the distinction between "the "high" politics of political principle and the "low" politics of partisan advantage', which he thought that the Court had demonstrated.

73 See AJ Scirica, 'Judicial Governance and Judicial Independence' (2015) 90 NYULRev 779, 799.

74 See W Sinnott-Armstrong, 'Recusal and Bush v. Gore' (2002) 21(2) Law and Philosophy $221,246-7$.

${ }_{75} 28$ USC section 2106; Cahill v New York, New Haven \& Hartford R.R. Co., 351 US 183 (1956).

76 Kennedy J in Calderon $v$ Thompson, 523 US 538, 557 (1998).

77 Supreme Court Rules (2013) R.44; generally, R Krimbel, 'Rehearing Sua Sponte in the U.S. Supreme Court: A Procedure for Judicial Policymaking’ (1989) 65 Chi-KentLRev 919. 


\section{CURRENT/ONGOING PROCEEDINGS}

The responses to ongoing proceedings (the 'third scenario') are more varied than those just discussed. Bias/recusal applications in ongoing proceedings raise jurisdictional questions which are often linked to process. ${ }^{78}$ The approaches emerging from the case law to these questions, which are all problematic, may be divided into four broad categories (discussed below).

\section{A. The Collegiate Panel Cannot Hear the Application}

Jackson J of the US Supreme Court famously said;

The unusual feature of the petition in this case is that it suggests to the Court a question as to the qualification of one of the Justices to take part in the decision of the cause. This petition is addressed to all of the Court and must either be granted or denied in the name of the Court and on the responsibility of all of the Justices. In my opinion the complaint is one which cannot properly be addressed to the Court as a whole and for that reason I concur in denying it ... There is no authority known to me under which a majority of this Court has power under any circumstances to exclude one of its duly commissioned Justices from sitting or voting in any case. ${ }^{79}$

The first point concerns process - addressing the petition to the entire court is a fatal procedural flaw. The second concerns jurisdiction-a majority of the Court has no power to prevent a Justice from sitting or voting. Thus, when a Justice rejects a recusal application that is the end of the matter. ${ }^{80}$ Some leading Supreme Court decisions have enjoyed the dubious protection offered by this approach, and have been rightly criticized. ${ }^{81}$ What the applicable standards require in each case is contentious, ${ }^{82}$ but that issue is beyond the scope of this discussion.

This approach is also strongly reflected in Ugandan jurisprudence. In Uganda Polybags Ltd v Development Finance Co. Ltd ${ }^{83}$ the Supreme Court of Uganda,

${ }^{78}$ See eg Black J in Re Murchison 99 L Ed 942, 946 (1955); Marshall J in Marshall v Jerrico Inc. 446 US 238, 242 (1980).

79 Jewell Ridge Coal Corp. v Local No. 6167, 325 US 897, 897 (emphasis added).

80 See eg Microsoft Corp. v US, 147 L.Ed.2d. 1048 (2000); Bush v Gore (n 72); Cheneyv United States District Court, 158 L. Ed. 2d. 225 (2004).

${ }^{81}$ See eg (on Cheney v United States District Court), AR Oakes and H Davies, 'Process, Outcomes and the Invention of Tradition: The Growing Importance of the Appearance of Judicial Neutrality' (2011) 51 SantaClaraLRev 573; (on Bush v Gore), W Sinnott-Armstrong, 'Recusal and Bush v. Gore' (2002) Law and Philosophy, 21(2) 221; RK Neumann Jr, 'Conflicts of Interest in Bush v. Gore: Did Some Justices Vote Illegally?' (2003) 16 GeoJLegalEthics 375. See also the excellent analysis of the possible cognitive illusions at play in some of these decision in SL Buhai, 'Federal Judicial Disqualification: A Behavioral and Quantitative Analysis' [2011] OrLRev 69.

82 On the Cheney case (above), contrast for example, A Olowofoyeku, 'Subjective Objectivity: Judicial Impartiality and Social Intercourse in the US Supreme Court' [2006] PL 15, with Pearson, 'Duck Duck Recuse? Foreign Common Law Guidance \& Improving Recusal of Supreme Court Justices' (n 68) 1799.

${ }^{83}$ [2000] UGSC 13. 
rejecting a petition challenging the refusal of a member of a Constitutional Court panel to recuse himself from hearing the appeal, said:

[W]e hold the view that the decision whether a Judge should disqualify himself or herself from sitting in a case where charges of bias or likelihood of bias are levelled against him or her, must be left entirely in his or her discretion. It would be improper for the rest of the members of the Coram to determine that issue ... which they have no jurisdiction to do. ${ }^{84}$

Similarly, the Seychelles Court of Appeal recently condemned the decision of a majority of a Constitutional Court panel to override the decision of a member of the panel who had declined to recuse himself. In Government of Seychelles $v$ Seychelles National Party ${ }^{85}$ ('Government of Seychelles') the Court of Appeal said that the court 'does not have self-policing powers to deny a fellow member of a Bench his right to function as a judge in any given case whether in public interest or otherwise'. ${ }^{86}$ In the Court's view, 'That one Constitutional Court of three judges should suddenly transform itself into a two Bench Constitutional Court is an illegitimate assumption of power' ${ }^{87}$

The Ontario Divisional Court adopted an approach that is consistent with this in $S O S{ }^{88}$ Two judges disagreed with the refusal of the third judge to recuse himself. They accepted that they could not order him to stand down, ${ }^{89}$ so they recused themselves instead (a tribute to judicial ingenuity, but an inappropriate application of the bias rule). The Supreme Court of Ireland seemed more flexible in Rooney $v$ Minister for Agriculture. ${ }^{90}$ Keane CJ indicated that a judge facing a recusal application should follow the established and prudent practice' of disqualifying himself 'if he has any reservations about the matter'. However, in cases of difficulty, the judge could refer the issue, "perhaps on the basis of a memorandum prepared by him or her - to the senior available judge of the court of which he is a member'. Keane CJ felt that such a course 'would be acceptable in cases of particular difficulty', but did 'not believe that this procedure should develop into common practice'. The decision is thus still a matter for the individual judge, who may choose to follow the exceptional procedure suggested by Keane CJ, but, it seems, may also choose not to follow it. ${ }^{91}$ Nothing was said about the situation in which a judge considers himself or herself to not be disqualified, but the other judges on the panel disagree, and there was no suggestion that the other panel members have the jurisdiction to insist on that judge stepping down.

\footnotetext{
${ }^{84}$ At 3-4 of the judgment. The Ugandan Constitutional Court adopted the same approach in Besigye v Attorney General [2006] UGCC 1. ${ }^{85}$ [2014] SCCA 33. ${ }^{86}$ Domah JA, at [11]. 87 At [34]. 88 (2005) 18 CPC (6th) $286 . \quad$ At [20].

90 [2001] 2 IRLM 37, 40-41.

91 Murphy J did choose to follow it in Blehein $v$ St. John of God [2001] IESC 73.
} 
The bulk of these decisions reject the jurisdiction of a collegiate court panel to disqualify a panel member. This jurisdictional deficit, about which more will be said later, is a difficult objection to overcome.

\section{B. The Collegiate Panel Can Hear the Application}

There have been a number of cases in which a challenge against a member of a collegiate court was considered by the full panel. This is an especially problematic approach. The decision of the South African Constitutional Court in SARFU, ${ }^{92}$ which involved applications for the recusal of half of the members of the Court, exemplifies this approach. Following the agreement of all the counsel in the case about the best way to proceed, the Court heard the application 'simultaneously by the whole Court'. This agreement by counsel marks the case as exceptional, and should be taken into account when analysing the decision. The Court considered that it was its duty 'to give collective consideration to the question whether the judges concerned should recuse themselves'. ${ }^{93}$ In conformity with orthodox common law practice, the starting point was that 'Judges have jurisdiction to determine applications for their own recusal'. ${ }^{94}$ A wrong decision on that point can be corrected on appeal. ${ }^{95}$ Then came the bombshell;

If one or more of its members is disqualified from sitting in a particular case, this Court is under a duty to say so, and to take such steps as may be necessary to ensure that the disqualified member does not participate in the adjudication of the case. ${ }^{96}$

This is the approach that was rightly condemned in Government of Seychelles. The SARFU Court added:

If one judge, in the opinion of the other members of the Court, incorrectly refuses to recuse herself or himself, that decision could fatally contaminate the ultimate decision of the Court, and the other members may well have a duty to refuse to sit with that judge. ${ }^{97}$

This resembles the dubious approach that was adopted by the Ontario court in $S O S$. The apparent authority for the $S A R F U$ propositions was the statement of Centlivres JA in $R v$ Milne and Erleigh ${ }^{98}$ that a judge who is disqualified on grounds of bias and continues to preside at a criminal trial commits 'an irregularity in the proceedings every minute he remains on the bench during the trial'. The Court then apparently found in the Pinochet case authority for another proposition - that 'if a judge incorrectly refuses to recuse herself or himself the remaining members of a panel should not sit with that judge as

92 [1999] ZACC 9. See also the Supreme Court of Swaziland in Attorney General v Simelane [2014] SZSC 77, [2015] 4 LRC 300. 93 [1999] ZACC 9 at [30]. 94 ibid [31]. 95 ibid. 99 ibid. 932$]. \quad 981951$ (1) SA 1, 6H (AD). 
the proceeding would be irregular'. ${ }^{99}$ It has been observed earlier in this article that each member of a collegiate court panel has a 'legitimate interest' in the impartiality of all the others. But this suggestion of a 'duty to refuse to sit with' a judge that the other panellists consider to be disqualified takes that interest to new heights. Furthermore, neither the statement of Centlivres JA in $R v$ Milne and Erleigh nor the Pinochet decision are authorities for these statements of the Court, and the 'recusals' in SOS, proceeding along identical lines (and designed to leave the non-recusing judge 'out on a limb') are similarly suspect.

Unfortunately these $S A R F U$ pronouncements have been cited with approval and followed - first, as will be seen below, by the East African Court of Justice ('EACJ') - but also in South Africa itself. ${ }^{100}$ In Nyong'o, ${ }^{101}$ the EACJ, noting the refusal of Keiwua $P$ to recuse himself from the appeal, said that the Court agreed with his position, and that his response should be deemed to have been incorporated into the Court's own decision. ${ }^{102}$ On the question of process, the Court commended the 'procedure practiced in the East African Partner States', which was similar to that advocated by the Constitutional Court of South Africa, namely that:

[C]ounsel for the applicant seeks a meeting in chambers with the judge or judges in the presence of [the] opponent. The grounds for recusal are put to the judge who would be given an opportunity, if sought, to respond to them. In the event of recusal being refused by the judge the applicant would, if so advised, move the application in open court. ${ }^{103}$

While this procedure may be suitable for a single-judge court, it is not clear how it would operate in a collegiate court. Its first leg, (proceedings in chambers), would be unproblematic only if the impugned judge agrees that recusal is warranted. In any other case, the format of the subsequent proceedings 'in open court' is not clear-whether they would involve a hearing before the impugned judge only, or a hearing in a full (collegiate) sitting of the court. Presumably, the latter is envisaged, with the court then deciding the matter collectively, which raises process and jurisdictional questions.

99 [1999] ZACC 9, [32].

100 See General Council of the Bar of South Africa v Geach [2012] ZASCA 175, [90] (SCA, South Africa); SACCAWU v Irvin \& Johnson Ltd [1999] ZALAC 17 Labour Appeal Court, South Africa); upheld by the Constitutional Court, 2000 (3) SA 705. See also Singh v North Central and the South Central Local Councils [1998] ZALCC 21 (Land Claims Court, South Africa).

${ }_{101}$ AG of Kenya v Prof. Anyang' Nyong'o [2007] EACJ 1.

102 At 26 of the judgment.

103 SARFU [1999] ZACC 9, [50]. The Caribbean Court of Justice recommended a similar procedure in criminal trials in $R v$ Lewis [2007] CCJ 3 (AJ), [49]. See also the New Zealand Court of Appeal in Smith v AG [2010] NZCA 258, [8]-[9]. 
The approach whereby the whole panel hears the application can also be seen elsewhere. In Yong Vui Kong v Attorney General ${ }^{104}$ the Singapore Court of Appeal jointly rejected an application for the recusal of Keong CJ. It is not clear what to make of the approach of the Supreme Court of Papua New Guinea in Supreme Court Reference No 1 of $2012^{105}$ where an application for the recusal of Injia CJ and Kirriwom $J$ from the five-judge panel failed. Both declined to recuse themselves, Gavara-Nanu J did not mention the bias issue at all, while Salika DCJ and Sakora J declined to publish their opinions for reasons expressed in court. In Sengupta $v$ Holmes ${ }^{106}$ Laws LJ rejected an invitation to recuse himself, with Jonathan Parker and Keene LJJ delivering concurring judgments. Similarly, in Baker v Quantum Clothing Group, ${ }^{107}$ Sedley LJ declined to recuse himself. Jacob and Smith LJJ also delivered a joint judgment, and 'concluded that this was not a case for recusal'. In $R$ (Syed and another) $v$ Secretary of State for the Home Department ${ }^{108}$ Richards LJ (Patten and Gloster LJJ concurring) declined an invitation to recuse himself. Finally, in DWR Cymru Cyfyngedig v Albion Water 109 another application for the recusal of Richards LJ was rejected. Sir Anthony Clarke MR delivered the lead judgment, with Longmore and Richards LJJ delivering brief concurring judgments. ${ }^{110}$

It is noteworthy that the question 'who should decide?' was not addressed directly in these cases; but the Employment Appeal Tribunal ('EAT') did address it directly in British Car Auctions Ltd. v Adams. ${ }^{111}$ Langstaff J said that 'Just as when a challenge is made to a Tribunal as a whole, that Tribunal must as a whole determine it, so must a Tribunal as a whole determine a challenge made to one individual on it.' ${ }^{112} \mathrm{He}$ reiterated, in providing guidance to employment tribunals, that 'where an allegation is made against one member or two of a Tribunal of three, the Tribunal as a whole must as a whole deal with those allegations in accordance with [the relevant] case law'. ${ }^{113}$ While clear guidelines are helpful, the approach being mandated is problematic. The source of the jurisdiction to disqualify a fellow panellist must be queried. It is well enough if the entire panel agrees to dismiss the recusal application, but, in addition to the issue of jurisdiction, another substantial difficulty with this approach relates to what happens in cases of

104 [2011] SGCA 9, [2012] 2 LRC 439 (CA, Singapore); reviewed (but not on the bias issue) by S Dam, 'Presidential Pardon in Singapore: A Comment on Yong Vui Kong v Attorney-General' (2013) 42(1) Common Law World Review 48. [2012] PGSC 20, [2012] 5 LRC 633.

106 [2002] EWCA Civ. 1104; noted by T Vollans, 'Judicial Bias: A Voyage from Appearance to

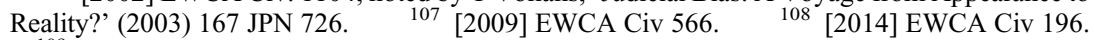
109 [2008] EWCA Civ 97.

110 Compare the Supreme Court of Papua New Guinea in Yama v Bank South Pacific [2008] PGSC 41. See also $R v$ Manyeli [2008] LSCA 29 (CA, Lesotho); Sole v Cullinan [2003] LSHC 19 (HC, Lesotho); Marematlou Freedom Party v Independent Electoral Commission [2007] LSHC 88; Law Society of Lesotho v Ramodibedi [2003] LSHC 28 (where one judge dissented).

111 UKEAT/0159/12/SM (EAT, 23 April 2013). 112 ibid.

113 At [31]. See also Peter Simper \& Co Ltd. v Cooke (No. 1) [1984] ICR 6; WestLB AG London Branch $v$ Pan, UKEAT/0308/11/DM (EAT, 19 July 2011). 
disagreement in the court. This is not purely academic, as the debacles in Government of Seychelles and SOS demonstrate. If the impugned judge sees no reason to stand down, but the rest of the panel/court disagree, it is not clear what 'steps' can be taken, as suggested in $S A R F U$, to prevent that judge from sitting. Unless the entire panel is in agreement, this approach places all concerned in an invidious position.

\section{Mixed Approaches?}

The cases appear to reveal a mixture of approaches in New Zealand and Australia, straddling the kinds of individual and collegiate decision-making discussed above. Nottingham $v T \& O r s^{114}$ and Reekers $v R^{115}$ seem to be collective recusal decisions (with the participation of the impugned members) of New Zealand Court of Appeal panels, but the Court has nevertheless emphasized that recusal is a decision for the individual judge. For example, Anderson J said in Erris Promotions $v$ Inland Revenue that, while 'in practice a Judge may seek a colleague's views, ultimately the decision must be for the particular Judge. There is no authority for another judge in the same jurisdiction to rule on the issue.' ${ }^{116}$ In $R v$ Chatha ${ }^{117}$ Glazebrook J confirmed that 'Even in a multi-member Court, recusal decisions are for the individual Judge.'118 Subsequently, in the same case ${ }^{119}$ the Court dismissed several applications for the recusal of three of the judges of the Court, and, then, of the entire Court. Glazebrook $\mathbf{J}$ reiterated ${ }^{120}$ the principle that, even in multi-member courts, a recusal decision is for the individual judge, and that there is no mechanism or jurisdiction for a recusal decision of a superior court to be "reviewed" by another panel'. ${ }^{121}$ According to her, 'Whether, in addition to any right of appeal, there should be a mechanism provided for review of a recusal decision by another panel is a policy matter that would need to be addressed by Parliament and/or in the rules of Court.' 122 This statement is significant, and points to what may well be the ultimate solution, not only in respect of reviews of recusal decisions, but also in respect of hearing recusal applications. Mixed approaches can be seen also in decisions of the New Zealand Supreme Court. ${ }^{123}$

Some Australian cases appear to show similarly mixed approaches. In Livesey $v$ New South Wales Bar Association ${ }^{124}$ a bench of the New South Wales Court of Appeal jointly considered and dismissed applications for the recusal of two of the three Justices in the case. While the High Court of Australia disagreed with the lower court's conclusion that the two Justices

114 [2001] NZCA 108.

115 [2011] NZCA 125.

116 [2003] NZCA 163, [22]. See also Glazebrook J in McDonald v New Zealand Law Society

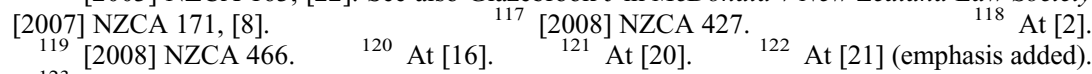

123 Contrast for example Taunoa $v A G$ [2006] NZSC 94; Jessop $v R$ [2007] NZSC 96, with Siemer v Heron [2011] NZSC 116. 
should not have recused themselves, no adverse comment was made on the procedure adopted by the court. On the other hand, in the High Court of Australia, Gageler J, in a decision that seemed to have been his alone, recused himself in Unions NSW v New South Wales. ${ }^{125}$ Interestingly, Callinan $\mathrm{J}$ in Kartinyeri $v$ Commonwealth ${ }^{126}$ first declined to recuse himself, but, then apparently did so subsequently. ${ }^{127}$

Where an impugned judge decides to step down, or sees no reason to step down and the other members of the panel agree, there is no problem. The difficulty arises where an impugned judge sees no valid ground for recusal, but the other panellists disagree. An impasse might be avoided if the suggestion of Glazebrook $\mathrm{J}$ in $R v$ Chatha' ${ }^{128}$ that the 'concurrence of the other members of the panel in any decision would be sought', and that, if 'any of the other Judges had a concern, this would almost inevitably lead to a recusal application being granted' materialized. In Smith v AG, ${ }^{129}$ the New Zealand Supreme Court approved as 'appropriate' and 'standard practice' the procedure followed by the Court of Appeal, whereby, following receipt of the applicant's written material, the judges on the panel met and discussed among themselves whether in the circumstances any of them should withdraw. These situations presume goodwill, implicit trust and good neighbourliness between judges. While such may readily be available in New Zealand and some other places, they may not be so readily available everywhere. In particular, they may be rare commodities in politicized or ideologically divided apex courts. It would be unsafe to rely wholly or significantly on such comity, as this could be vulnerable to manipulation and abuse.

\section{Referral to Another Judge}

Callinan $\mathrm{J}$ of the High Court of Australia thus suggested in Ebner v Official Trustee;

If there is no legal inhibition upon it, and if it is convenient for it to be so made, I think it preferable that such a decision be made by another judge. That procedure would better serve the general public interest and the litigants in both the appearance and actuality of impartial justice. ${ }^{130}$

However, other members of the Court took issue with this suggestion, saying;

Adopting such a procedure would require examination of the power of that other judge to determine the question and the way in which that other judge's conclusion would find its expression. In particular, is the question of possible 
disqualification to be treated as an issue in controversy between the parties to the proceeding and is it to be resolved by some form of order? ... it is sufficient to say that, in our view, Goldberg J adopted what was both the ordinary, and the correct, practice in deciding the matter himself. ${ }^{131}$

It is significant that Callinan $\mathrm{J}$ himself prefaced his suggestion with the words '[i]f there is no legal inhibition upon it', thereby revealing his own doubts. Nevertheless, this kind of approach has found favour in the UK, ${ }^{132}$ and was recently adopted by the Seychelles Court of Appeal. ${ }^{133}$ This solution is creditable - but the proper process for its adoption needs to be considered carefully.

\section{THE CASE FOR LEGISLATION}

In making the case for legislation, I will first examine the common law's dilemmas regarding reopening judgments and in ongoing proceedings, and will follow these with an analysis of why the common law's approaches are inappropriate and why the common law is ill-equipped to resolve these dilemmas.

\section{A. Reopening Judgments}

It is reasonable that, to prevent substantial injustice, apex courts should have an exceptional jurisdiction to reopen (and, if necessary, vacate) their own judgments on grounds of bias. Arguably, public confidence in the administration of justice would suffer if apex courts were to refuse stubbornly to respond appropriately to obvious substantial injustice. Thus, most of the final courts in the foregoing analysis claim this 'inherent' jurisdiction. An intermediate appellate court may turn out to be a final court in certain situations. In those situations, it would also need the exceptional jurisdiction just referred to. The Court of Appeal in England made that clear in Taylor $v$ Lawrence. ${ }^{134}$ Its powerful reasoning was formally adopted by the Court of Appeal of Belize in RBTT Trust Ltd v Flowers. ${ }^{135}$ The Federal Court of Malaysia came to the same conclusion in MGG Pillai v Tan Sri Dato' Vincent Tan Chee Yioun. ${ }^{136}$ The concept of a jurisdiction to prevent or correct substantial injustice is, in itself, unobjectionable. But, in an apex court, this prospect has ramifications for finality in litigation. It should not be lightly exercised, and, indeed, is not. Nevertheless, such a jurisdiction and its

\footnotetext{
131 Gleeson CJ, McHugh, Gummow and Hayne JJ, at [74] (emphasis added).

132 See Ward LJ in El-Farargy v El Farargy [2007] EWCA Civ. 1149, [32]; applied in Tricor PLC (Formerly PNC Telecom PLC) v HMRC [2014] UKFTT 241 (TC).

133 Government of Seychelles, [2014] SCCA 33. ${ }^{134}$ [2002] EWCA Civ. 90, [2003] QB 528.

135 [2013] 1 LRC 147 (Mendes JA at [18]-[20], [25]; Carey JA at [77]). See also the Court of Appeal of the Bahamas in Maycock v Commissioner of Police [2015] 3 LRC 183, [23]-[24] and [111]-[114].

136 [2003] 2 LRC 339.
} 
parameters ought arguably to be expressly conferred and defined by legislation, and not just asserted by courts or developed in adversarial litigation. Of crucial concern is the inability of common law adversarial litigation to engage wider inputs, seek consensus, or give adequate consideration to broader issues, and possibly unexpected consequences.

\section{B. Current/Ongoing Proceedings}

It has been seen that the common law generally expects judges to determine recusal applications concerning themselves personally. This is sufficiently controversial regarding solo judges, but assumes added dimensions when the impugned judge is sitting with others. The judge's decision may compromise the others, making it undesirable for the decision to be left to him or her. Nonetheless, difficulties might arise should the other panellists wish to determine the matter. From the discussions above, at one end of the spectrum, they have every right to seek to decide the matter, while, at the other end, such an intervention would constitute an illegitimate assumption of jurisdiction. There appears to be no middle ground. This is the dilemma of the common law in ongoing proceedings.

If it is problematic for impugned judges to be the final arbiters of their own recusal in ongoing proceedings, it is even more so in an apex court, if the ultimate remedy lies in the prospect of subsequently moving that court to vacate the ensuing substantive decision. It would be a waste of time and resources to file a recusal motion, have it rejected by the impugned judge, wait until judgment, then file another application for that judgment to be vacated because the impugned judge had continued to sit while disqualified. But a party who waits until final judgment before complaining about an alleged disqualifying factor could face the 'waiver' argument. Judges could possibly always respond to applications for them to recuse themselves with 'prudence'137; but judges also have a 'duty to sit'. ${ }^{138}$ The balance between the duty to sit and the duty to withdraw when required can be elusive, and, inevitably, some judges will get it wrong - a prospect that raises particular issues for collegiate courts.

Hammond has rightly observed that the 'least developed, but arguably the most important, aspect of recusal law lies in the processes adopted, if not expressly formulated, by courts'. ${ }^{139}$ He says that there should be well 'understood methods for dealing with recusal concerns'. ${ }^{140}$ However, it is

137 AWG Group v Morrison [2006] EWCA Civ 6, [2006] 1 WLR 1163, [9].

138 See generally, JW Stempel, 'Chief William's Ghost: The Problematic Persistence of the Duty to Sit Doctrine' (2009) 57 BuffLRev 813; also Robbie The Pict v Her Majesty's Advocate, 2003 SCCR 99, [16]; O’Neill No 2 v HM Advocate [2013] UKSC 36, [50]; Ex parte CJL (1986) 161 CLR 342, 352 (HC, Australia); SARFU at [48].

139 G Hammond, Judicial Recusal: Principles, Process and Problems (Hart 2009) 71.

140 ibid 76. 
apparently not enough that the procedure should be 'well understood', as Hammond also notes:

The overwhelming deficiency however is the obvious concern that the judge, required to be impartial, must decide whether he or she is sufficiently impartial to decide the case. Of all the offences against the legal process criteria, this last must be a candidate for a condign sentence. ${ }^{141}$

Hammond says that the solution is 'straightforward' as far as collegiate courts are concerned, and that the panel appointed to the case should consider whether the objection is well founded. ${ }^{142}$ In so saying, he also proposes that the impugned judge could have input, or even sit with his or her colleagues. Hammond recognizes that this latter suggestion is a 'concession' to old practice, but says that the outcome should be for the panel as a whole. However, this does not avoid the difficulties arising from the involvement of the impugned judge.

More pertinent to the present discussion is Hammond's statement that 'the really critical point is that if it is thought to be necessary, for example, on a five-judge panel, four judges could vote the impugned judge off'. ${ }^{143}$ Hammond cites no authority for this proposition, but we have already examined this kind of response in SARFU. Apparently, if this panel is a properly constituted quorate panel, then the outcome would be the same as that of any quorate panel (the decision of the majority holds, and all members of the panel must respond accordingly). ${ }^{144}$ This suggestion, as has been seen in the discussions in section $\mathrm{V}(\mathrm{A})$ above, is emphatically and rightly rejected in a number of jurisdictions. Hammond does not address the question what would happen in the event that the judge concerned refuses to be 'voted off' on the ground that the other members lack the necessary jurisdiction. His omission to address this may just reflect his expectation that judges would simply accept the majority's decision. This is a reasonable expectation, especially where the matter is not about the judge. However, while a refusal may be improbable in some places, ${ }^{145}$ it is not inconceivable. Indeed, it would seem likely in a politicized or ideologically divided court, especially one that sits en banc. Hammond also does not address the question what happens in the (very realistic) event that the other judges on the panel are evenly divided on the recusal issue, such that the impugned judge has the decisive vote. Presumably, the same majority principle would apply, but such a result would hardly inspire public confidence.

Pearson, ${ }^{146}$ borrowing from the SARFU decision, advocates a 'three-step procedure' for the US Supreme Court. The first is a face-saving private request to the impugned Justice. The next step (if the Justice refuses to stand

\footnotetext{
141 ibid. 142 ibid 149.143 ibid. 144 ibid.

145 See eg Glazebrook J in $R v$ Chatha [2008] NZCA 466, [16]; Blehein v St. John of God [2001] IESC 73.

${ }^{146}$ Pearson (n 68) 1799, 1836.
} 
down) is a formal written motion addressed to the impugned Justice. The final step would be an appeal for en banc review of the Justice's recusal decision, reserved 'for situations when there is a compelling reason for intervention'. ${ }^{147}$ However, this process does not meet the objections to the involvement of the impugned judge, who is personally involved in two of the three proposed steps. Pearson's and Hammond's proposed approaches, like that commended by SARFU and endorsed in Nyong'o, are therefore still problematic. They also face jurisdictional difficulties. The power of members of a collegiate court (especially an apex court) to prevent any of its duly commissioned judges from sitting is neither one that should be lightly assumed, nor one that should be asserted on the basis of implication. It is not difficult to imagine the kinds of mischief that could ensue were an apex collegiate court to arrogate to itself such a power. This kind of power arguably requires legislative authority.

\section{Fatal Contaminations}

The question whether the disqualification of one member must trigger the disqualification of the entire panel remains contentious. This arises mainly in connection with challenges to judgments; but it is also relevant to ongoing proceedings. With regard to the former, the South African Constitutional Court seemed to consider in $S A R F U$ that one panellist's disqualification would fatally contaminate the others. ${ }^{148}$ The Supreme Court of Canada indicated strongly in Weywakum ${ }^{149}$ that this is not necessarily so, particularly in cases where the 'vote' of the disqualified judge was not decisive. The majority in SOS also agreed that, since each judge had reached his own judgment independently, the decision was not tainted by the alleged bias of one judge. ${ }^{150}$ This issue was not addressed directly in the other cases, and it does not assist this inquiry that, in most of these cases, the allegations of bias were dismissed. The Pinochet, Kenny, and other similar decisions may seem to point towards a positive response, but this does not necessarily follow. Pinochet involved the disqualification of one of a 3-2 majority, where clearly that one vote did swing the decision, and in Kenny, the Supreme Court of Ireland decided to 'err on the side of caution', ${ }^{151}$ but did not address this issue at all. Lord Kerr did say in Lesage v Mauritius Commercial Bank Ltd ${ }^{152}$ (involving the decision of a two-judge panel of the Supreme Court of Mauritius, one of whom had been sent privileged information by a party) that, "Where the appearance of unfairness or bias has been established, ordering a new trial free from the taint of that manifestation is unavoidable." This statement,

\footnotetext{
147 ibid 1839.

150 (2005) 18 CPC (6th) 286, [9].

148 [1999] ZACC 9, [32].

152 [2012] UKPC 41, [2013] 4 LRC 330, [60].
}

149 [2003] 2 SCR 259, [91]-[93].

151 [2008] 2 IR 40, 46. 
while apparently unqualified, must be considered in the context of the case (a unanimous decision of a two-judge panel).

In Competition Commission v BAA Limited (Ryanair Ltd intervening) ${ }^{153}$ the English Court of Appeal did not accept the proposition that the recusal of one member of a panel necessarily contaminates the remaining members. Maurice Kay LJ referred ${ }^{154}$ with apparent approval to the following statement of Andrew Smith J in ASM Shipping Ltd v Bruce Harris: ${ }^{155}$

I am unable to accept that there is an invariable rule, or it is necessarily the case, that where one member of a tribunal is tainted by apparent bias the whole tribunal is affected second-hand by apparent bias, and therefore should recuse themselves, or should be excluded, from the proceedings. After all, it is common practice where a juror has to be discharged ... for the judge to consider whether there is a risk of 'contamination' of other jurors, and if there is no reason to think that there is, to continue the trial with the remaining jurors.

The Competition Appeal Tribunal recently faced this issue in Sky UK Ltd and others $v$ Office of Communications (Top UP TV Europe Ltd and others intervening). ${ }^{156}$ The Chair (Barling J) recused himself. The remaining members of the panel did not recuse themselves, and (the Chair agreeing ${ }^{157}$ ) did not consider themselves 'tainted'. 158

On this question, where judges have heard a case together (whether completed or not), it would indeed be unedifying to open 'difficult evidentiary questions' as to the extent to which a disqualified panel member may have influenced the others. On account of the principle that appearances are 'just as important as the reality' ${ }^{159}$ in bias cases, and of the concerns with maintaining public confidence in the administration of justice, it is arguable that the disqualification of a panellist must be considered a fatal contaminant for the others. This is particularly so when the hearing has commenced, or judgment has been delivered. This would be a problematic proposition for apex courts that sit en banc. Such courts face a unique problem-there is no other panel to preside over a rehearing if the judges are all deemed contaminated, or if they vacate a judgment. In the latter case, the parties would, on the basis of necessity, have to reargue the case before judges all of 'whom had already expressed their conclusion on the points at issue'. Unless the rehearing panel is composed entirely of ad hoc judges or judges from outside the jurisdiction, such an outcome is inescapable. But a panel comprising such judges would almost invariably be unacceptable, if not constitutionally impossible. This casts the reservations of the Canadian Supreme Court in Wewaykum in a new, positive light. It would be problematic to treat one member's disqualification as a fatal contaminant of the entire court in these cases. Where a judgment has been 
vacated, a rehearing before the same court (minus the disqualified judge) would be pointless, other than perhaps as a symbolic gesture. One pragmatic response would be simply to discount the vote of the disqualified judge. This is a difficult proposition that might require legislative authority. Additionally, there would be a real risk of an eventually evenly-split court. Furthermore, it does not address the issue of the possible influence of the previous participation of the disqualified judge on the others. The problem is intractable.

The pill might be easier to swallow given something akin to R.44(1) of the US Supreme Court Rules (2013), which requires a petition for rehearing to be rejected unless it is 'at the instance of a Justice who concurred in the judgment or decision', and denies oral hearings in respect of such petitions. But this skirts the real issue-ie, what happens to en banc proceedings/ decisions allegedly tainted by the participation of a disqualified judge? There is no problem-free response-and, in the absence of direct statutory/ constitutional provision, the answer may be 'nothing'-which is unsatisfactory. The 'pragmatic response' referred to above may be the best of a range of troublesome options for final courts that sit en banc. But, since such response would require a satisfactory answer about the source of the assumed jurisdiction, this problem would best be addressed by legislation.

\section{Public Confidence}

There are enduring difficulties surrounding bias in collegiate courts. None of the approaches deriving from case law and academic commentary seen so far is unproblematic. Hammond has rightly observed that this aspect of recusal law requires development. ${ }^{160}$ The question is the form that such development should take. Part of the problem lies in the nature of the common law itself, which typically does not seem overly concerned about internal processes. The common law's promotion of personal recusal decision-making is troublesome, ${ }^{161}$ but well-established. It may take a long time (if ever) for the common law to address it. An appropriate and convincing response is, however, necessary if judges are to maintain public confidence (described by Arden LJ in Mengiste $v$ Endowment Fund for the Rehabilitation of Tigray 162 as 'society's trust and confidence') in the administration of justice. Public confidence is a difficult concept, and the questions of the correct weight to be attached to it, ${ }^{163}$ or how best to protect or maintain

\footnotetext{
160 Compare D Bam, 'Making Appearances Matter: Recusal and the Appearance of Bias' (2011) BYULRev 943, 944-6.

161 See generally S Ifill, 'Do Appearances Matter?: Judicial Impartiality and the Supreme Court in Bush v Gore' (2002) 61 MdLRev 606; D Goldberg et al., 'The Best Defense: Why Elected Courts Should Lead Recusal Reform' (2007) 46 WashburnLJ 503.

162 [2013] EWCA Civ 1003; noted by M Ahmed, In Practice: Legal Update: Civil Procedure: Judicial Recusal (2013) LS Gaz, 14 October, 26.

${ }_{163}$ See eg S Atrill, 'Who is the Fair-Minded and Informed Observer"? Bias after Magill' (2003) 62 CLJ 279, 284.
} 
it $^{164}$ are controversial. So controversial are they that even the established concept that a party with 'an irresistible right to object to a judge hearing a case' is entitled to waive that right has been questioned on grounds of public interest and public confidence. ${ }^{165}$ However, it has rightly been observed that, '[w]hether seen as a principle of natural justice or a core constitutional value, the notion is fundamental'. ${ }^{166}$

Perceptions are obviously important. Langstaff J noted in Elys $v$ Marks and Spencer plc ${ }^{167}$ that 'what underpins the principles in respect of bias and appearance of bias as they have developed ... is the principle that justice should be apparent and transparent, and that strenuous efforts must be taken to ensure that justice does not forfeit the respect to which it is entitled'. He accepted that 'when the tribunal is concerned with allegations that it, the tribunal or a member of it, has been biased or there has been a material procedural irregularity because of the conduct which it has permitted or, more particularly, of which a member of it is guilty, the tribunal is no longer concerned with facts relating to the conduct of others. It is, in effect, assessing its own conduct.' ${ }^{168} \mathrm{He}$ also recognized that, in such a situation, 'the tribunal might be thought to be judge and jury in its own case'. ${ }^{169}$ Nevertheless, the tribunal still needs to consider the matter itself. 170

Thus, although a perception problem is recognized, it will not be addressed. Failing to respond arguably challenges the bias rule's quest to maintain public confidence. Since the perception problem seems insufficient to precipitate action, there are perhaps also questions as to which (or whose) conception of 'public confidence' is engaged, and the standards required by that conception. There are clear statements of the standards-first, that the 'indispensable requirement of public confidence in the administration of justice requires higher standards today than was the case even a decade or two ago', ${ }^{171}$ and, secondly, that the judiciary must strive to maintain a high level of public trust and confidence, holding itself to 'exacting standards lest it lose its legitimacy and suffer a loss of public confidence'. ${ }^{172}$ As to whose conception is engaged, Lord Denning MR said in Metropolitan Properties Ltd $v$ Lannon that 'justice is rooted in confidence', and that 'confidence is

\footnotetext{
164 See eg RJ McKoski, 'Giving up Appearances: Judicial Disqualification and the Apprehension of Bias' (2015) 4 BrJAmLegStudies 35, 61, 66-7, 69; C Campbell, 'Judges, Bias and Recusals in Australia' in HP Lee (ed), Judiciaries in Comparative Perspective (CUP 2011) 279, 285, 290-2.

165 See K Malleson, 'Safeguarding Judicial Impartiality' (2002) 22 LS 53, 58. Contrast M Groves, 'Waiver of the Rule Against Bias' (2009) 35 MonLR 315, 319-23, arguing that public confidence might be enhanced 'if waiver is found in an appropriate case' (at 320).

166 J Kleefeld, 'Pinochet and Loc[a]bail: English Developments in the Law of Bias' (2000) 58 Advocate Vancouver 851, 860 (internal citations omitted). Compare C Grayling, 'Apparent bias in planning decisions: whose fair-minded and informed view counts? $R$ (on the application of Lewis) $v$ Redcar and Cleveland BC' (2009) 28(2) CJQ 191, 198.

167 [2014] ICR 1091 (EAT), [12]. ${ }_{169}$ At [11].
171 Lawal v Northern Spirit Limited [2003] UKHL 35, [22].
172 Spear J in Sun Exploration and Production Co v Jackson (1989) 783 SW 2d 202, 206.
} 
destroyed when right-minded people go away thinking that the judge was biased'. ${ }^{173}$ While this statement related to the substantive decision in the case, it is equally relevant to process. Public confidence is essential not only in respect of the courts' decisions, but also in respect of their processes, ${ }^{174}$ and a flawed/problematic process is as liable to damage public confidence as a flawed decision. Thus, the required conception of public confidence is arguably that of 'right-minded people'. 'Right-minded people' is possibly as elusive a construct as the 'informed observer', but we must equally engage with it and consider what would maintain or damage that construct's confidence. In that context, French CJ observed in Cesan $v R$ that there are 'elements of the judicial process which can be said, at least in a metaphorical way, to play a part in maintaining public confidence in the courts irrespective of their relationship to the actual outcome of the process' ${ }^{175}$ Applying this to the present discussion, involvement of the impugned judge or other fellowpanellists arguably raises a public perception problem. 'Right-minded people' might 'go away thinking that the [court] was biased', not on account of the actual decision, but on account of who made the decision (the impugned judge, and/or his or her colleagues on the panel), and how it was made (following a private conference between the impugned judge and his or her 'mates').

The ECtHR has stated that a court or tribunal must, in addition to being subjectively impartial, 'also be impartial from an objective viewpoint, that is, it must offer sufficient guarantees to exclude any legitimate doubt in this respect'. ${ }^{176}$ It is questionable whether the personal involvement of the impugned judge or his or her fellow panellists in the recusal decision would offer the required 'sufficient guarantees'. It has rightly been noted that the rationale for the principle that one cannot be a judge in one's own cause is that 'in cases where the judge is himself a party or has a direct proprietary or pecuniary interest in the litigation it is impossible to maintain that there is no real danger or possibility of the judge being biased. In other words, it would be impossible to guarantee the judge's impartiality.' ${ }^{177}$ This is the same as stating that the required 'sufficient guarantees' would be lacking. Clearly, a judge facing a recusal application does not thereby become a party to or acquire an interest in the litigation. Nevertheless, the judge is still being mandated by the common law to adjudicate on a matter that directly affects him or her. This involves a decision by 'the ultimate insider, the judge whose

173 [1969] 1 QB 577, 599 (emphasis added).

174 Compare W Phillips, 'Complaints against judges and public confidence in the judiciary: does South Australia need a complaints handling body?’ (2014) 33(4) CJQ 427, 432.

175 (2008) 236 CLR 358, 380; [2008] HCA 52, [71] (HC, Australia) (emphasis added).

176 See Pullar v UK (1996) 22 EHRR 391, [30]; Findlay v UK (1997) EHRR 221, [73] (emphasis added).

${ }_{177}$ P Havers QC and O Thomas, 'Bias Post-Pinochet and Under the ECHR' [1999] JR 111, 112. 
impartiality is being questioned'. ${ }^{178}$ One could sympathize with the view that this process 'is not a policy calculated to promote vigorous enforcement'. ${ }^{179}$

The $S A R F U$ court notably said:

... the judges whose recusal was sought, and the remainder who were asked to look to their conscience, considered their own positions individually, and also considered the application as a whole, collectively, and concluded unanimously that none should be recused. ${ }^{180}$

While lawyers/judges might be content to leave matters to the consciences of impugned judges, it is possible that other 'right-minded people' might not be so sanguine. Except in the most obvious cases wherein the allegations of bias are manifestly unfounded (almost to the point of being scurrilous), perhaps only the most trusting would consider that such a situation affords 'sufficient guarantees to exclude any legitimate doubt' about impugned judges' impartiality as far as their own recusal decisions are concerned.

Furthermore, there are issues of legitimacy, which is one reason why bias/ recusal law is concerned about public confidence. In this respect, Oakes and Davies have explained that:

Empirical studies that locate the issue of legitimacy at the heart of the law's authority stress the role of fair institutional procedures in fostering internalized compliance, but in this respect what seems to be important is the role of appearance; citizens' acceptance of institutional legitimacy depends in large measure on the extent to which the procedures of the institution or decisionmaking body are perceived to be procedurally fair. ${ }^{181}$

This relates to perceptions of the procedural fairness of the internal recusal processes. It would arguably boost legitimacy and public confidence by ensuring that the recusal procedures of collegiate courts 'are perceived to be procedurally fair' if neither the impugned judge nor the collegiate panel were involved in the decision. A decision made outwith the affected panel would arguably stand a better chance of maintaining the confidence of right-minded people in the integrity of the judicial system than the status quo.

\section{E. Cognitive Illusions}

Apart from the above considerations, there is much to commend independent adjudication over the current common law approaches. Groves has argued that 'the apparently objective nature of the fair minded and informed observer is often a mirage and that judges frequently impose their own subjective opinions rather than those of any objective

\footnotetext{
178 McKoski (n 164) 35, 59.

179 D Goldberg et al., 'The Best Defense: Why Elected Courts Should Lead Recusal Reform' [2007] 46 WashburnLJ 503, 524.

${ }_{180}$ [1999] ZACC 9, 1999 (4) SA 147, at [34].

181 AR Oakes and H Davies, 'Process, Outcomes and the Invention of Tradition: The Growing Importance of the Appearance of Judicial Neutrality’ (2011) 51 SantaClaraLRev 573, 573.
} 
person'. ${ }^{182}$ This is said to be an 'imperfect device' which 'may only be as fair or open minded as each judge allows'. ${ }^{183}$ Henry, in a paper which sought to discount the value of an appearance of impartiality, made a crucial, albeit not earth-shattering observation - that 'judges are subject to their own values and opinions'. ${ }^{184}$ This observation can be expanded into 'heuristics' that can trigger 'cognitive illusions and faulty decision making'. ${ }^{185}$ According to Buhai, such illusions 'are particularly problematic when a judge is called upon to decide whether he can decide impartially - in effect, to decide whether he is competent to perform, in a particular case, the role to which he has dedicated his life'. ${ }^{186}$ Buhai examines these at length in her excellent paper. The 'heuristics' (mental shortcuts relied upon to make complex decisions ${ }^{187}$ ) facilitate efficient decision-making, but can also produce 'severe and systematic errors in judgment' 188 by creating misperceptions (ie, 'cognitive illusions') that can 'skew our decisions'. 189 She explains that 'Cognitive illusions, like optical illusions, deceive us without our being fully aware that we are being deceived'. ${ }^{190}$ She lists 'Five common heuristics' which 'influence decision making in law', viz:

anchoring (making estimates based on irrelevant starting points); framing (treating economically equivalent gains and losses differently); hindsight bias (perceiving past events to have been more predictable than they actually were); the representativeness heuristic (ignoring important background statistical information in favor of individuating information); and ... egocentric biases (overestimating one's own abilities). ${ }^{191}$

Buhai's point is that 'judges are not immune to the effects of heuristics and the resulting cognitive illusions'. ${ }^{192}$ Therefore, 'judges making recusal decisions, and those who worry about the law of judicial recusal need to be aware of how heuristics can bias a judge's decision to recuse himself - or, more likely, not to recuse himself'. ${ }^{193}$ This analysis simply highlights the dangers inherent in permitting judges to determine their own (actual) impartiality, and/or whether an informed observer would reasonably apprehend bias. But the concern here goes beyond appearances. It goes to the question of potential self-deception.

Buhai eventually examines ${ }^{194}$ the aforesaid five 'common heuristics' against a number of important United States federal recusal decisions, including Scalia J in the Cheney case, and Rehnquist $\mathrm{J}$ in Laird $v$ Tatum, and persuasively demonstrates that they (particularly anchoring, hindsight bias, and egocentric

\footnotetext{
182 M Groves, 'The Rule Against Bias' (2009) 39 HKLJ 485, 487.

183 ibid 514 .

184 G Henry, 'Pinochet: In Search of the Perfect Judge' (1999) 21 SydLRev 667, 674.

185 See SL Buhai, 'Federal Judicial Disqualification: A Behavioral and Quantitative Analysis' [2011] OrLRev 69, 70.

186 ibid (internal citations omitted from this and subsequent references). $\quad 187$ ibid 82.

188 ibid. 189 ibid. 190 ibid 83.

191 ibid, citing C Guthrie et al., 'Inside the Judicial Mind' (2001) 86 CornellLRev 777, 778

(emphasis added). 192 ibid (internal citations omitted). 193 ibid (emphasis supplied).

194 ibid $83 \mathrm{ff}$.
} 
bias) may have been at play in the decisions of these judges to continue to sit in those cases. Her observations about 'egocentric bias' are crucial:

[E]gocentric bias may make it difficult for judges to decide objectively whether they can act impartially in a particular case ... And, unlike anchoring and hindsight bias, this bias likely affects every decision made by a judge about himself - in other words, it likely affects every federal recusal decision. ${ }^{195}$

The outcome of Buhai's analysis is the submission that 'Review by others [of the recusal decisions of federal judges] is essential'. ${ }^{196}$ The point is well made, but this interposition of 'others' arguably comes too late. Impugned judges ought arguably not to decide the matter at all; and neither should those that they are sitting with.

\section{F. Judges Need 'Assistance'}

Some judicial voices (mostly writing extrajudicially) have endeavoured to address some of the difficulties discussed herein by supporting the idea of independent adjudication. ${ }^{197}$ They have generally not been heeded by their colleagues. This is hardly surprising, as it may be unrealistic to expect radical departures from established jurisprudence to come readily from within. The common law, fragmented, and developing incrementally in adversarial proceedings on a case-by-case basis, is ill-equipped to provide a complete response to the process and jurisdiction issues in particular. Nevertheless, the Seychelles Court of Appeal has recently bravely taken this on, formally adopting Sedley's suggestion. It put 'in black and white' 11 Rules for independent adjudication, 'drawn a lot from the suggestions of Lord [Justice] Sedley' which are 'to be used with imagination rather than dogmatically'. ${ }^{198}$ This is a valiant initiative, but it is questionable whether this kind of judicial legislation is appropriate. While radical reform is needed, such reform arguably ought not to come via a judicial decision, in a contentious case, without the benefit of wider input, and without detailed consideration of the potential for unintended consequences. Independent adjudication is a defensible solution, but the objections of the High Court of Australia in Ebner $v$ Official Trustee ${ }^{199}$ are formidable and convincing in establishing that the seismic shift required to implement it cannot and ought not to be judge-made.

Malleson has suggested that judges could do with 'the assistance of more formalised procedures and rules'. ${ }^{200}$ She points out that, in the aftermath of

195 ibid 97.

196 ibid 98 (emphasis added).

${ }^{197}$ For example, Hammond, above; S Sedley, 'When should a judge not be a judge?' 33(1) London Review of Books 9 (6 January 2011); Sedley's suggestion seems to be endorsed by Lord Neuberger in his F A Mann 2015 lecture, 'Judge not, that ye be not judged: judging judicial decisionmaking', [37]-[40] <https://www.supremecourt.uk/docs/speech-150129.pdf>.

${ }_{198}$ Government of Seychelles [2014] SCCA, [29].

${ }^{200} \mathrm{~K}$ Malleson, 'Judicial Bias and Disqualification after "Pinochet (no 2)"” (2000) 63(1) MLR $119,127$. 
the Pinochet decision, the then Lord Chancellor, Lord Irvine wrote 'an open letter to Lord Browne-Wilkinson' (the Senior Law Lord), suggesting 'that the decision-making process should be a collective one addressed by the panel of judges before hearing each case and that responsibility for ensuring that a judge who had a conflict of interest did not sit should be that of the law lord in the chair'. ${ }^{201}$ The suggestion does not address matters that come to light later in a case, but was widely reported. ${ }^{202}$ The Irish Times reported that Lord Irvine's comments 'met with a tepid response from former Master of the Rolls Lord Donaldson', who did not see the need for a 'radical overhaul', but that 'Lord Scarman, a retired Law Lord, agreed with Lord Irvine'. ${ }^{203}$ This is but one example of how senior judges may differ on fundamental issues, perhaps justifying the view that judges do need the assistance of formalized processes.

\section{G. Legislative Assistance}

Legislation could viably provide the required assistance. Legislation is able to address any wider issues, embrace representations from a broad audience, seek consensus, confer the necessary jurisdictions, assess and account for potential consequences, and address any democratic deficit or legitimacy issues. It is submitted that addressing satisfactorily the issues and difficulties examined above requires legislation (primary or subordinate). Examples of legislativelyprescribed recusal processes exist. Some provide for 'peremptory disqualification', with litigants having one right to request ('in good faith') the disqualification of a judge for 'personal' bias. While some require a disqualification application to be 'legally sufficient', ${ }^{204}$ some do not. ${ }^{205}$ Peremptory disqualification is controversial, ${ }^{206}$ and a similar US Federal statute relating to federal district court judges (28 USC section 144) has been judicially interpreted virtually out of existence. ${ }^{207} \mathrm{I}$ am advocating something different.

201 ibid 126.

202 See eg The Guardian, 'Senior law lord told to make sure embarrassment is not repeated', 18 December 1998 <http://www.theguardian.com/uk/1998/dec/18/1>; BBC News, 'Lord Chancellor: Ensure future impartiality', 17 December $1998<$ http://news.bbc.co.uk/1/hi/uk_politics/237007. stm>; BBC News, 'Pinochet case “damaged" UK justice', 28 December $1998<\mathrm{http}: / /$ news.bbc. co.uk/1/hi/uk_politics/243444.stm>.

203 J Wilson, 'Law lord allegation "brought system into disrepute", The Irish Times, 29 December $1998<\mathrm{http}: / / w w w . i r i s h t i m e s . c o m / n e w s / l a w-l o r d-a l l e g a t i o n-b r o u g h t-s y s t e m-i n t o-$ disrepute-1.229311>.

204 See eg Utah Rules of Civil Procedure, R.63(b)(3)(A).

205 For example the Alaska Statutes (section 22.20.022) dealing with district or superior court actions. On this see generally M Greenstein, 'Judicial Disqualification in Alaska Courts' (2000) 17 AlaskaLRev 53.

206 For a proponent, see EM Martin, 'Disqualification of Federal Judges for Bias under 28 U.S.C. Section 144 and Revised Section 455' (1976) 45 FordhamLRev. 139.

207 See generally JP Frank, 'Disqualification of Judges' (1947) 56 YaleLJ 605; DL Bassett, 'Judicial Disqualification in the Federal Courts' (2002) 87 IowaLRev 1213. 
In the international sphere, the Statute of the ICJ stipulates that recusal/bias matters 'shall be settled by the decision of the Court'. ${ }^{208}$ Article 24(2) also permits the President, if he or she considers that, for some special reason one of the members of the Court should not sit in a particular case, to 'give him notice accordingly'. Any disagreement between the member of the Court and the President on the issue 'shall be settled by the decision of the Court'. ${ }^{209}$ The Statute of the ITLOS provides for the matter to 'be resolved by decision of the majority of the other members of the Tribunal present'. ${ }^{210}$ As with the ICJ, the President, is also permitted to give notice to any member that he or she considers that, for some special reason, should not sit in a particular case. $^{211}$ Arguably the best international example is Rule 15(B) of the ICTY Rules of Procedure, which empowers the President to appoint a panel of three Judges drawn from other Chambers to report to him its decision on the merits of an application for disqualification and withdrawal of a judge, and to assign another judge to replace the impugned judge in the event of the application being successful. The substance of these processes are (apart from the ICTY Rules) questionable in that they involve the affected panel in the decision. ${ }^{212}$ Nevertheless they have the virtues of being embedded in the Courts' Statutes/Rules, and of their removal of the impugned judges from the decision-making process. In particular, they provide a satisfactory (ie, legislative) answer to jurisdictional questions.

One commendable domestic example is Rule 18a of the Texas Rules of Civil Procedure, which stipulates that a motion to recuse or disqualify a judge should be filed with the clerk of the court in which the case is pending. ${ }^{213}$ The respondent judge should thereupon either stand down, or refer the motion to the regional presiding judge, ${ }^{214}$ who must either rule on it, or assign it to another judge. Where the respondent is the regional presiding judge, then he or she may still assign a judge to hear the motion, or refer it to the Chief Justice for consideration. ${ }^{215}$ These and the ICTY Rules are valuable legislative templates.

It is argued here that legislation removing the recusal decision from the affected panel would be a significant improvement over the status quo. It may be considered that this argument would encounter difficulties deriving from bias cases being fact-specific. However, the envisaged difficulty is more apparent

\footnotetext{
208 Arts 16, 17 and 24. See also Legal Consequences of the Construction of a Wall in the Occupied Palestinian Territory, Order of 30 January 2004, ICJ Rep (2004) at 3; generally, GI Hernández, 'Impartiality and Bias at the International Court of Justice' (2012) 1(3) CJICL 183.

209 Art 24(3).

210 Arts 7, 8. Compare Rule 8(6), Rules of Court, African Court on Human and People's Rights. 211 Art 8(3).

212 The principle of 'necessity' may well apply where there is no other body able to decide the matter.

213 Rule $18 \mathrm{a}(\mathrm{a})$.

214 Rule $18 \mathrm{a}(\mathrm{f})$.

215 Rule $18 \mathrm{a}(\mathrm{g})$. See also California Civil Procedure Code, section 170.3(c)(5). Compare the Alaska Statute on disqualification 'for cause' (section 22.20.020(c)); R.63(b)(3)(2) of the Utah Rules; R.40(e)(3) of the Vermont Rules of Civil Procedure.
} 
than real. First, it should be reiterated that this discussion relates, not to the application to specific factual situations of the relevant bias standards, but, rather, to the questions who decides, and how the decision ought to be taken (ie, process and jurisdiction). These are questions not affected by factsensitivity. It is true that the courts 'appear to have considerable difficulty in applying [the test for apparent bias] consistently', making the decision look 'dangerously like a case-by-case, and not a principled, approach', ${ }^{216}$ and that the interposition of the 'informed observer' and the attributes attached thereto are problematic (although it may be overstating it to say that this has 'caused confusion' ${ }^{217}$ ). It is also possible that this situation would not be improved by any legislation dealing with process and jurisdictional issues. However, the kind of independent adjudication being advocated may achieve greater consistency. A considerable number of recusal appeals consist of attempts to validate (or otherwise), ex post facto, a failure to self-recuse. A decision taken by another judge stands a better chance of objectivity, and avoids the potential embarrassment of having to find ways to validate a decision that really ought to be overthrown (and the invidious position of a judge (or his or her fellow panellists) having to make the decision on whether that judge was compromised).

Secondly, the following statement of Lord Hope of Craighead in Gillies $v$ Secretary of State for Work and Pensions should be noted:218

The question whether the fair-minded and informed observer would conclude that there was a real possibility that the tribunal was biased cannot, of course, be answered without looking at the facts ... But the question whether a tribunal was properly constituted or was acting in breach of the principles of natural justice is essentially a question of law. It requires a correct application of the legal test to the decided facts ... there can be only one correct answer to the question whether the tribunal was properly constituted. So to answer the question incorrectly is an error of law.

Determining questions of law is par excellence a judicial function, and the bias standards are well developed (even if often uncertain in application ${ }^{219}$ ). Factsensitive or not, and legislative process or not, if an impugned judge can rightly decide the question, so can another judge. As to the factual basis upon which the decision ought to be predicated, Richards LJ said in $R$ (Condron) $v$ National Assembly for Wales that 'the court must look at all the circumstances as they appear from the material before it ...'220 Again, any judge is competent to evaluate the factual material before the court, and to make the required decision - a point well-made and endorsed by Mummery LJ in $A W G$

216 H Stout, 'Bias' [2011] JR 458, 478.

217 Atrill (n 163) 279, 279-80.

218 [2006] UKHL 2, [2006] 1 WLR 781, [6].

219 For a general critique of 'appearance-based disqualification', and its alleged failure to bring 'uniformity, consistency, or predictability to recusal decisions', see McKoski (n 164) 35.

${ }^{220}$ [2006] EWCA Civ 1573, [2007] 2 P. \& C.R. 4, [50]. 
Group Ltd v Morrison. ${ }^{221}$ Appellate courts reviewing recusal decisions of lower courts invariably do this. In short, there is little, other than precedent or convenience, to commend personal recusal decision-making over independent adjudication.

What is envisaged is legislation providing for recusal/disqualification applications to be heard by designated judges or a specially constituted panel of judges, applying the established bias standards, with perhaps one level of appeal from their decision. An impugned judge only needs to be involved with regard to fact-finding. In the UK for example, the decision-makers could consist of designated judges of the Administrative Court (or the Court of Appeal) sitting alone, with one final appeal/review before a three-judge bench of the same court. This is only one possible configuration. The Texas Rules and the ICTY Rules provide other worthy configurations. The crucial factors are (a) the introduction of legislation and, (b) removal of the panel with the impugned judge(s) from the process. 'Fishing expeditions' can be addressed by a requirement to obtain leave.

\section{CONCLUSION}

In sum, it is submitted that it would be inappropriate for bias allegations in a collegiate court to be resolved by the affected panel or any member thereof, that the decision should be removed from that panel, and that this new process ought to be implemented by legislation. Legislating for independent adjudication of bias claims could (perhaps with provision for replacing disqualified judges in apex courts ${ }^{222}$ ) resolve satisfactorily the issues addressed in this article. The difficulties attending the vacation on grounds of bias of judgments of apex courts that sit en banc (or discounting the vote of a disqualified judge) are more intricate, and are of such serious constitutional import that constitutional-level responses beyond ordinary legislation may be needed. But, at the very least, the issues must be addressed directly and resolved definitively, and, legislation is warranted. This would require political will and consensus, and probably also significant support from the senior judiciary and the legal profession.

${ }^{221}$ [2006] EWCA Civ 6, [2006] 1 WLR 1163, [20]. See also Lord Phillips MR in In Re Medicaments, at [31].

${ }_{222}$ See generally, R Black and L Epstein, "Recusals and the "Problem" of an Equally Divided Supreme Court' (2005) 7 Journal of Appellate Practice and Process 75; A Olowofoyeku, 'Regulating Supreme Court Recusals' [2006] SingJLS 60. 